\title{
Food habits of the yellow snapper Lutjanus argentiventris (Peters, 1869) (Percoidei: Lutjanidae) in La Paz Bay, Mexico
}

\author{
Hábitos alimenticios del pargo amarillo Lutjanus argentiventris (Peters, 1869) \\ (Percoidei: Lutjanidae) en la Bahía de La Paz, México \\ Rosa I. Vázquez ${ }^{1}$, Jesús Rodríguez ${ }^{1}$, Leonardo A. Abitia ${ }^{2}$ and Felipe Galván² \\ ${ }^{1}$ Centro de Investigaciones Biológicas del Noroeste, S.C., Mar Bermejo 195, Apdo. Postal, 128 \\ La Paz, Baja California Sur, México, C.P. 23090 \\ ${ }^{2}$ Centro Interdisciplinario de Ciencias Marinas, Instituto Politécnico Nacional CICIMAR, Apdo. postal 592, \\ La Paz, Baja California Sur, México. C.P. 23096 \\ ivazquez@cibnor.mx
}

\begin{abstract}
Resumen.- Se analizaron 304 estómagos del pargo amarillo Lutjanus argentiventris recolectados bimestralmente de abril 2003 a abril 2004, de los cuales 44\% presentó alimento (44\%). Se identificaron 54 tipos de presa. De acuerdo con el índice de importancia relativa (IIR), los huevos de peces (62\%) y los peces Harengula thrissina (23\%), Porichthys margaritatus (3,3\%) y Abudefduf troschelii (2,3\%) fueron las presas de mayor importancia en su dieta. En los juveniles, las presas de mayor importancia fueron la materia orgánica no identificada (32\%), los crustáceos Upogebia pugettensis (29\%) y los camarones peneidos (6,5\%), así como los huevos de peces (5,2\%). El índice de Levin determinó que la amplitud de la dieta fue baja ( $\mathrm{Bi}=$ $0,0002)$, siendo considerado un depredador selectivo, mostrando un consumo preferencial por los huevos de peces y $H$. thrissina. El mismo resultado se obtuvo para machos $(B i=0,0002)$ y hembras $(B i=0,0009)$. Los juveniles mostraron una baja amplitud de dieta, consumiendo principalmente materia orgánica no identificada y $U$. pugettensis. El índice de Morisita-Horn mostró un traslapo significativo en la dieta por sexo, $(\mathrm{C} \lambda>0,6)$, mientras que para juveniles y adultos se registró un traslapo bajo $(\mathrm{C} \lambda<0,6)$, reflejando la diferencia de su hábitat.

Palabras clave: Pargo amarillo, espectro trófico, presas importantes, Golfo de California
\end{abstract}

Abstract.- A total of 304 yellow snapper Lutjanus argentiventris stomachs were sampled bimonthly from April 2003 to April 2004, of which 44\% contained food. We identified 54 prey species. From the index of relative importance (IRI), fish eggs (62\%), Harengula thrissina (23\%), Porichthys margaritatus (3.3\%), and Abudefduf troschelii (2.3\%) were the prey of greatest importance in its trophic spectrum. In juvenile snappers, the most important preys were unidentified organic matter (32\%), the crustacean Upogebia pugettensis (29\%), penaeid shrimp (6.5\%), and fish eggs (5.2\%). The Levin index determined that the diet breadth was low $\left(B_{i}=0.0002\right)$, indicating that it is a specialist predator showing preference for fish eggs and $H$. thrissina. The same result was found in males $(B i=0.0002)$ and females $(B i=0.0009)$. Although juveniles also showed a low trophic breadth, they preferred unidentified organic matter and $U$. pugettensis. The Morisita-Horn index showed considerable overlap in diet between genders $(C \lambda>0.6)$, though diet overlap was low between juveniles and adults $(\mathrm{C} \lambda<0.2)$ reflecting feeding habitat differences between them.

Key words: Yellow snapper, trophic habits, main prey, Gulf of California

\section{Introduction}

The fish of the family Lutjanidae, commonly known as snappers, are a fishing resource of great importance in the Gulf of California, mainly along the southeastern coast of Baja California Sur (Rodríguez et al. 1994). In La Paz bay the yellow snapper Lutjanus argentiventris (Peters, 1869 ) is an important fishery resource, yielding close to $8 \mathrm{t}$ per year (Ramírez 1996). Their high quality meat is sold fresh or frozen (Berdegué 1956, Fischer et al. 1995).

Lutjanus argentiventris is a demersal species with adults inhabiting rocky and coral reefs or in caves between rocks. The juveniles live mainly in mangroves, where they form small aggregations (Fischer et al. 1995, Thomson et al. 2000).

Several studies on the trophic biology of fish of the family Lutjanidae showed that snappers are predators with variable feeding habits. All are carnivores, feeding mainly on fish and benthic crustaceans, e.g. decapods, cephalopods, and gastropods (Allen 1987, Díaz 1994, Sierra et al. 1994, Rojas 1997, Thomson et al. 2000). They are also known to eat seaweed, sponges, salps, and worms (Díaz 1994, Sierra et al. 1994). 
For the yellow snapper, Maeda (1981) found that $L$. argentiventris feed on decapods, fish, and amphipods in the lower Gulf of California. Also, Leventhal (1982) and Funes \& Matal (1989) mentioned that this snapper feeds on crustaceans, mainly penaeid shrimp, stomatopods, xanthids, and portunids. The knowledge of snapper trophic biology is incomplete and the present study contributes on the trophic dynamics of this species.

\section{Material and methods}

The yellow snapper was sampled bimonthly from April 2003 to April 2004 in estuaries and fishing camps in La Paz bay, mainly off El Portugues, El Saladito, San Juan de la Costa, La Gaviota, and Espiritu Santo Island (San Gabriel and El Cardonal) (Fig. 1).

The fish were caught using various devices including line and hook, trawler nets, harpoon, and traps. The total length (TL), standard length (SL), weight (g), and gender of each specimen were recorded. The stomachs were extracted and preserved in $10 \%$ formalin. The fullness

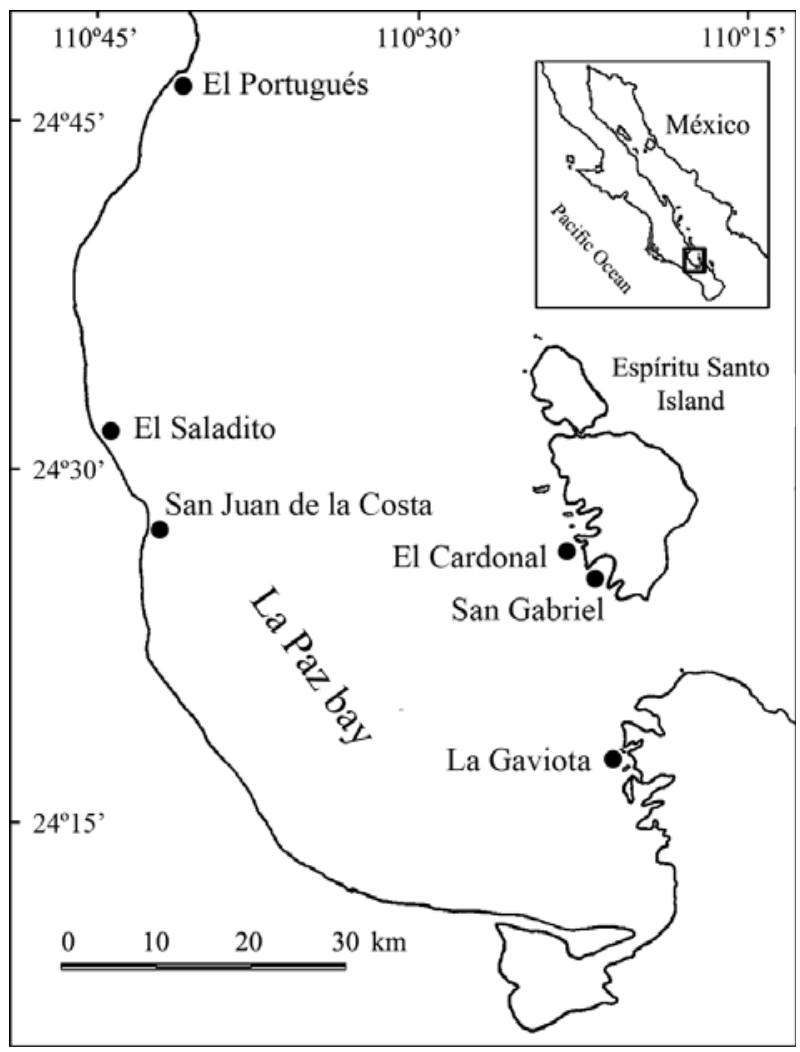

Figure 1

La Paz bay and sampling locations

Localización de Bahía de La Paz y áreas de muestreo was determined following the methodology of Stillwell \& Kohler (1982).

Prey species were identified to the lowest possible taxon, using specialized literature and keys. For fish in a minimum state of digestion, the keys of Miller \& Lea (1972), Eschmeyer et al. (1983), Allen \& Robertson (1994), and Fischer et al. (1995) were used. For fish in an advanced state of digestion, we used the keys of Clothier (1950) and Miller \& Jorgensen (1973). The fish skeleton collection from the Laboratorio de Ecología de Peces del Centro Interdisciplinario de Ciencias Marinas (CICIMAR) at La Paz, Mexico, was useful for prey verification. Crustaceans were identified using Brusca (1980) and Fischer et al. (1995). Worms were identified with Bastida (1991), and cephalopods with Iverson \& Pinkas (1971).

The diet was analyzed by calculating three methods for each prey taxon. We calculated (1) frequency of occurrence (\%FO), (2) by using gravimetric methods (\%W), and (3) numerical (\%N) following Hyslop (1980). We also combined these methods to calculate the index of relative importance of Pinkas et al. (1971). IRI is a commonly used measure that provides a summary of dietary composition (Cailliet et al. 1986).

$$
I R I=(\% \mathrm{~W}+\% N) * \% F O
$$

where $\% \mathrm{~N}$ is percentage of number of organisms, $\% \mathrm{~W}$ is percentage of weight; \% FO is percentage of frequency of occurrence.

By using the absolute values of the numeric method, the diet breadth was calculated using the Levin standardized index (Krebs, 1989) following Labropoulou \& Eleftheriou (1997)

$$
\left.B_{i}=1 / n-1\left\{\left(1 / \sum p i j^{2}\right)-1\right)\right\}
$$

where $B_{i}$ is the Levin Index for predator $i$; pij is the proportion of the diet of predator $i$ that is made up of prey $j$, and $n$ is number of prey species.

This index assumes values from 0 to 1 . When $B_{i}$ is near zero, the predator is a specialist because it has a preference for only a few prey species. A value of $B_{i}$ near 1 is a generalist predator, which consumes a higher prey species without a preference for any specific one.

Trophic overlap between gender and between juvenile and adult organisms was analyzed using the Morisita-Horn Index (Smith \& Zaret 1982) as 


$$
\underset{i=l}{C} \lambda=2 \sum(P x i \times P y i) /\left(P x i+\sum_{\substack{P y i \\ i=l}}^{n}\right.
$$

where $C \lambda$ is the Morisita-Horn index, $P x i$ is the proportion of prey $i$ of the total of prey used by predator $x$, and Pyi is the proportion of prey $i$ used by predator $y$. The possible values of $\mathrm{C} \lambda$ are from 0 to 1 . The scale proposed by Langton (1982) was used in which $\mathrm{C} \lambda$ values between 0 and 0.29 indicate low overlap, 0.30 and 0.59 indicate moderate overlap, and a $\mathrm{C} \lambda$ greater than 0.6 indicates high overlap. A value of 1 indicates that all prey items are shared in the same proportion by gender or length, indicating a total overlap.

\section{Results}

A total of 304 individuals of L. argentiventris were collected, of which $44 \%$ of the stomachs contained food. The standard lengths of yellow snappers were from 5.4 to $63 \mathrm{~cm}$. We found 54 prey taxa belonging to four general categories; crustaceans (28), fish (22), cephalopods (1), and worms (1). Unidentified organic and plant matter were also found (Table 1).

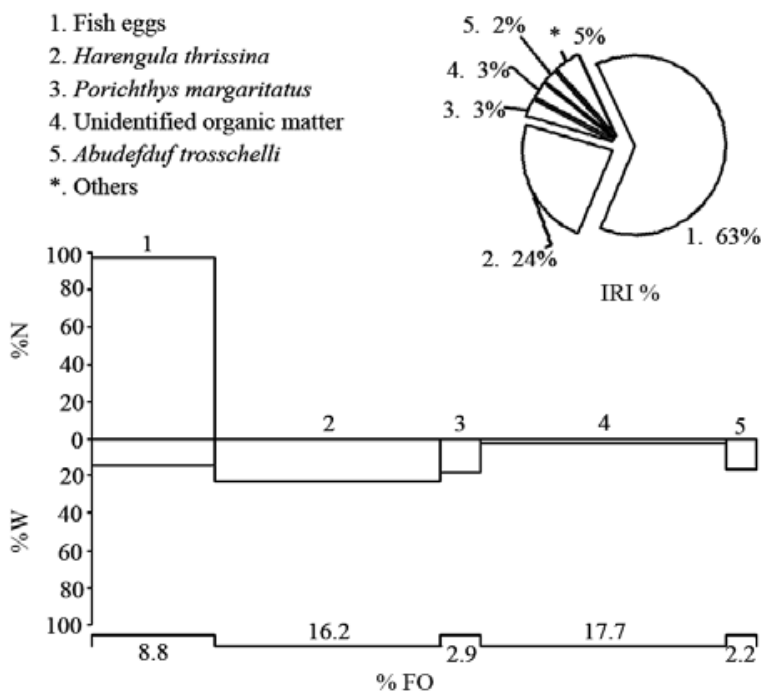

Figure 2

Yellow snapper (L. argentiventris) trophic spectrum in La Paz bay, Mexico, using number $(\mathrm{N})$, weight $(\mathrm{W})$, frequency of occurrence (FO) and index of relative importance (IRI)

Espectro trófico del pargo amarillo (L. argentiventris) en Bahía de La Paz, México, expresado en valores absolutos y porcentuales de los métodos numérico $(\mathrm{N})$, gravimétrico $(\mathrm{W})$, frecuencia de aparición (FO) e índice de importancia relativa (IRI)
According to the IRI, fish were the most important source of food in the diet of yellow snapper, where fish eggs (63\%) appeared to be most important prey item, followed by the sardine Harengula thrissina (24\%) (Fig. 2).

We found three groups by developing stage: a) male adult, b) female adult, and c) juvenile. A total of 32 males contained 32 prey species. According to the IRI, fish were $96 \%$ to the diet of the adult males. The most important prey types were fish eggs (56\%), $H$. thrissina (21\%), and the toad fish Porichthys margaritatus (16\%) (Fig. 3). The 39 adult females fed on 21 prey species, including fish eggs (68\%) and $H$. thrissina (24\%) (Fig. 3).

In the 64 juveniles we found twenty-one prey species. The IRI indicated that crustaceans (46\%) were the main food for juveniles, followed by unidentified organic matter (32\%), fish (21\%), and worms (0.1\%). The most important components in the juvenile diet were unidentified organic matter (32\%), followed by the mud shrimp Upogebia pugettensis (29\%), penaeid shrimp (7\%), and fish eggs (5.3\%) (Fig. 3).

The trophic breadth was low $\left(B_{i}=0.0002\right)$, which indicates that this species is a specialist because it fed mainly on only a few prey; fish eggs and $H$. thrissina. The same diet pattern was found in the male $(B i=0.0002)$, female $(B i=0.0009)$, and juvenile snapper $\left(B_{i}=0.027\right)$. The juveniles ate mainly unidentified organic matter and U. pugettensis.
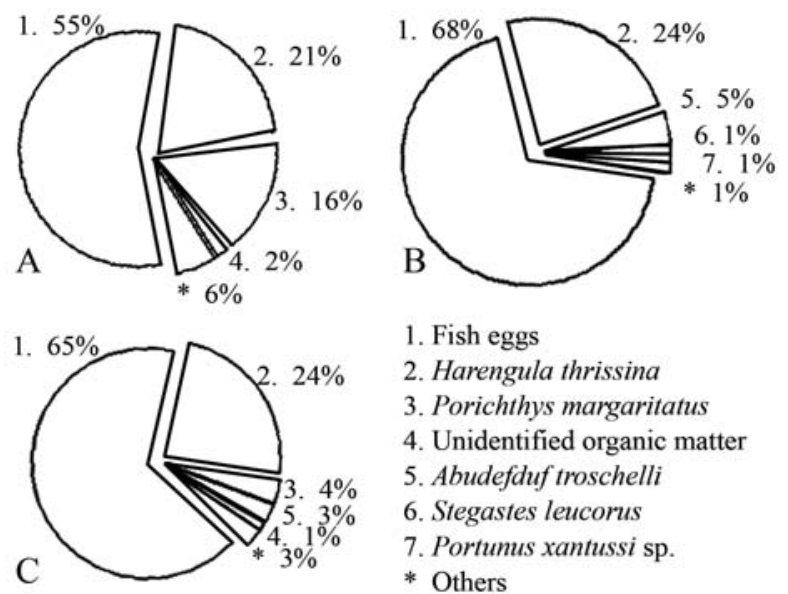

1. Fish eggs

2. Harengula thrissina

3. Porichthys margaritatus

4. Unidentified organic matter

5. Abudefduf troschelli

6. Stegastes leucorus

7. Portumus xantussi sp.

* Others

\section{Figure 3}

Main preys in the food by sex of $L$. argentiventris using \% IRI. A) Adult males, B) Adult females and C) Juveniles

Presas más importantes en la dieta por sexo de $L$. argentiventris, de acuerdo al \% IRI. A) Machos, B) Hembras y C) Juveniles 
Table 1

Prey composition of yellow snapper of Lutjanus argentiventris in La Paz bay, using percentage values of the number ( $N$ ), weight (W), frequency of occurrence (FO) and index of relative importance (IRI) methods

Espectro trófico del pargo amarillo Lutjanus argentiventris en la bahía de La Paz, expresado en valores porcentuales de los métodos numérico $(\mathrm{N})$, gravimétrico $(\mathrm{W})$, de frecuencia de aparición (FO), e índice de importancia relativa (IRI)

\begin{tabular}{|c|c|c|c|c|c|}
\hline Item & $\% \mathrm{FO}$ & $\% \mathrm{~N}$ & $\% \mathrm{~W}$ & IRI & $\%$ IRI \\
\hline \multicolumn{6}{|l|}{ Annelida } \\
\hline Lumbrineris spp. & 1.48 & 0.006 & 0.0005 & 0.010 & 0.0007 \\
\hline \multicolumn{6}{|l|}{ Crustacea } \\
\hline \multicolumn{6}{|l|}{ Stomatopoda } \\
\hline Squilla tiburonensis Schmitt 1940 & 0.74 & 0.003 & 0.545 & 0.406 & 0.025 \\
\hline Squilla hancocki Schmitt 1940 & 0.74 & 0.003 & 0.049 & 0.038 & 0.002 \\
\hline Pseudosquillopsis marmorata & 0.74 & 0.003 & 0.175 & 0.132 & 0.008 \\
\hline Penaeidae & 11.85 & 0.059 & 0.474 & 6.320 & 0.398 \\
\hline Metapenaeopsis spp. & 2.22 & 0.049 & 0.171 & 0.490 & 0.030 \\
\hline Litopenaeus spp. & 1.48 & 0.006 & 0.011 & 0.026 & 0.001 \\
\hline Farfantepenaeus spp. & 0.74 & 0.003 & 0.115 & 0.087 & 0.005 \\
\hline \multicolumn{6}{|l|}{ Sicyioniidae } \\
\hline Sicyonia disedwardsi & 0.74 & 0.003 & 0.080 & 0.061 & 0.003 \\
\hline \multicolumn{6}{|l|}{ Brachyura } \\
\hline Portunus xantusii & 7.41 & 0.072 & 1.360 & 10.611 & 0.668 \\
\hline Eurytium affine & 2.22 & 0.016 & 0.066 & 0.185 & 0.011 \\
\hline Panopeus purpureus & 1.48 & 0.013 & 0.023 & 0.054 & 0.003 \\
\hline Leptodius spp. & 0.74 & 0.003 & 0.017 & 0.015 & 0.000 \\
\hline Trapezia spp. & 0.74 & 0.003 & 0.005 & 0.006 & 0.000 \\
\hline Mitras spp. & 0.74 & 0.003 & 0.191 & 0.144 & 0.009 \\
\hline Callinectes bellicosus & 1.48 & 0.006 & 0.067 & 0.110 & 0.006 \\
\hline Herbstia camptacantha & 1.48 & 0.006 & 0.063 & 0.103 & 0.006 \\
\hline Xanthidae & 0.74 & 0.003 & 0.047 & 0.037 & 0.002 \\
\hline Brachyuran remains & 5.93 & 0.046 & 0.238 & 1.685 & 0.106 \\
\hline \multicolumn{6}{|l|}{ Anomura } \\
\hline Porcellanidae & 0.74 & 0.003 & 0.002 & 0.004 & 0.0003 \\
\hline Pleuroncodes planipes & 0.74 & 0.003 & 0.039 & 0.031 & 0.002 \\
\hline \multicolumn{6}{|l|}{ Thalassinidea } \\
\hline Neotryphaena spp. & 2.96 & 0.013 & 0.250 & 0.781 & 0.049 \\
\hline Upogebia pugettensis & 10.37 & 0.088 & 0.302 & 4.051 & 0.255 \\
\hline Excirolana spp. & 2.222 & 0.009 & 0.027 & 0.083 & 0.005 \\
\hline Nerocila californica & 1.481 & 0.019 & 0.033 & 0.078 & 0.004 \\
\hline Cirolana spp. & 1.481 & 0.003 & 0.047 & 0.074 & 0.004 \\
\hline Amphipoda & 2.963 & 0.049 & 0.022 & 0.211 & 0.013 \\
\hline Mysidacea & 2.963 & 1.244 & 0.166 & 4.180 & 0.263 \\
\hline \multicolumn{6}{|l|}{ Leptostraca } \\
\hline Nebalia spp. & 2.222 & 0.052 & 0.012 & 0.144 & 0.009 \\
\hline Subtotal & 70.370 & 1.792 & 4.607 & 30.160 & 1.900 \\
\hline
\end{tabular}


Table 1. continued

\begin{tabular}{|c|c|c|c|c|c|}
\hline Item & $\% \mathrm{FO}$ & $\% \mathrm{~N}$ & $\% \mathrm{~W}$ & IRI & \%IRI \\
\hline \multicolumn{6}{|l|}{ Mollusca } \\
\hline \multicolumn{6}{|l|}{ Cephalopoda } \\
\hline Dosidicus gigas & 0.740 & 0.003 & 2.223 & 1.649 & 0.103 \\
\hline \multicolumn{6}{|l|}{ Osteichthyes } \\
\hline \multicolumn{6}{|l|}{ Clupeidae } \\
\hline Harengula thrissina & 16.296 & 0.101 & 22.995 & 376.393 & 23.715 \\
\hline \multicolumn{6}{|l|}{ Synodontidae } \\
\hline Synodus spp. & 0.740 & 0.003 & 2.020 & 1.498 & 0.094 \\
\hline \multicolumn{6}{|l|}{ Myctophidae } \\
\hline Benthosema spp. & 2.222 & 0.009 & 0.378 & 0.862 & 0.054 \\
\hline \multicolumn{6}{|l|}{ Batrachoididae } \\
\hline Porichthys analis & 0.740 & 0.016 & 0.094 & 0.082 & 0.005 \\
\hline Porichthys margaritatus & 2.963 & 0.013 & 18.165 & 53.862 & 3.393 \\
\hline \multicolumn{6}{|l|}{ Belonidae } \\
\hline Platybelone argalus pterura & 0.740 & 0.003 & 1.225 & 0.910 & 0.057 \\
\hline \multicolumn{6}{|l|}{ Hemiramphidae } \\
\hline Hyporhamphus unifasciatus & 0.740 & 0.003 & 1.536 & 1.140 & 0.071 \\
\hline Holocentridae & 1.481 & 0.006 & 0.517 & 0.776 & 0.048 \\
\hline \multicolumn{6}{|l|}{ Syngnathidae } \\
\hline Syngnathus auliscus & 0.740 & 0.003 & 0.017 & 0.015 & 0.000 \\
\hline \multicolumn{6}{|l|}{ Scorpaenidae } \\
\hline Scorpenodes xyris & 0.740 & 0.003 & 0.047 & 0.037 & 0.002 \\
\hline Serranidae & 0.740 & 0.003 & 0.075 & 0.058 & 0.003 \\
\hline Sparidae & 0.740 & 0.003 & 0.165 & 0.125 & 0.007 \\
\hline \multicolumn{6}{|l|}{ Pomacentridae } \\
\hline Abudefduf troschelii & 2.222 & 0.009 & 16.679 & 37.087 & 2.336 \\
\hline Stegastes leucorus & 2.963 & 0.013 & 3.594 & 10.689 & 0.673 \\
\hline Gobidae & 4.444 & 0.023 & 0.645 & 2.972 & 0.187 \\
\hline Bathygobius spp. & 2.963 & 0.016 & 0.121 & 0.409 & 0.025 \\
\hline Gobulus spp. & 0.740 & 0.003 & 0.056 & 0.044 & 0.002 \\
\hline \multicolumn{6}{|l|}{ Tetraodontidae } \\
\hline Sphoeroides spp. & 0.740 & 0.003 & 1.303 & 0.9682 & 0.061 \\
\hline \multicolumn{6}{|l|}{ Diodontidae } \\
\hline Diodon spp. & 0.740 & 0.003 & 4.081 & 3.025 & 0.190 \\
\hline Fish eggs & 8.888 & 97.770 & 14.346 & 996.592 & 62.791 \\
\hline Fish larvae & 1.481 & 0.039 & 0.000 & 0.058 & 0.003 \\
\hline Fish remains & 10.370 & 0.046 & 1.821 & 19.364 & 1.220 \\
\hline Subtotal & 64.444 & 98.099 & 89.888 & 1506.97 & 94.949 \\
\hline Unidentified organic matter & 17.777 & 0.078 & 2.623 & 48.048 & 3.027 \\
\hline Vegetation & 2.222 & 0.013 & 0.123 & 0.303 & 0.019 \\
\hline TOTAL & & 100 & 100 & $\mathbf{1 5 8 7 . 1 4}$ & 100 \\
\hline
\end{tabular}


The Morisita-Horn index showed high overlap between female and male groups, indicating that both genders consumed the same prey (fish eggs and $H$. thrissina). We found a low overlap ( $\mathrm{C} \lambda<0.2)$ when we compared the diets between adults and juveniles.

\section{Discussion}

Other studies about the snapper diet showed they feed more on crustaceans and some fish (Claro \& Lapin 1971, Claro 1981, Guevara et al. 1994, Duarte \& García 1999). Also in our research we found that fish eggs were consumed by adults, and crustaceans by juveniles. Claro (1983) found in Cuban waters that snapper distribution and diet diversity suggest a general reliance on a wide spectrum of food resources, which ensures considerable resilience to trophic habitat disturbances.

Duarte \& García (1999) found 106 prey species in $L$. analis. However the diets of other snapper species are not very broad, including L. colorado with 30 items (Rojas 1997), L. synagris (30 items) (Sámano et al. 1998), L. guttatus (27 items) and L. griseus (22 items) (Sámano et al. 1998), L. guttatus (28 items) (Rojas 1996-1997), L. guttatus (88 items) (Rojas \& Chiappa 2002), L. apodus (11 items) (Rooker 1995). We found 54 prey items in the yellow snapper (L. argentiventris) from the lower Gulf of California, which represents a wider trophic spectrum when compared to other snappers, except with the prey number from L. guttatus (Rojas \& Chiappa 2002) and from L. analis (Duarte \& García 1999). The trophic spectrum for $L$. argentiventris indicates that it is a carnivorous-omnivorous predator, which consumes mostly benthic organisms, e.g. P. analis, P. margaritatus, Synodus spp., penaeid shrimp, Squilla tiburonensis, $S$. hancocki, etc. and a few pelagic species (Portunus xantusii). In general the yellow snapper is an opportunistic species that concentrates on prey with high availability. This trophic plasticity also has been observed in other species such as L. guttatus (Maravillas 2001) and $L$. synagris (Sámano et al. 1998).

Funes \& Matal (1989) characterized the yellow snapper as a carnivorous-omnivorous predator that feeds continuously on crustaceans throughout the year. The present work also indicated this high consumption of crustaceans throughout the year though crustaceans constitute the most important prey only for juveniles. The adults fed mainly on fish, represented mostly by fish eggs and the sardine $H$. thrissina.

Lutjanus argentiventris co-occurs with many of its prey species, such as Upogebia pugettensis in mangrove roots, and the Mithrax spp. and Herbstia camptacantha in coral reefs (Porites spp.) and these are found as important prey in their stomachs. Although the importance of brachyurans in the yellow snapper diet is evident, they could be underestimated because of the advanced state of digestion of some prey (Duarte \& García 1999). This is true mainly in juvenile snappers, because the unidentified organic matter is the most important food item found and could be remnants of crustaceans. The brachyurans are bottom dwellers and weak swimmers, which indicate that the yellow snapper it is a benthic predator (Duarte \& García 1999).

The yellow snapper does not have strong teeth for breaking the hard shells of bivalve mollusks (Claro 1981), however we did find some bivalve mollusks in the yellow snapper diet. Rojas (1997) found low rates of bivalve mollusks, echinoderms, and annelids consumed by other snapper species.

Algae and other vegetation were occasionally found in the yellow snapper stomachs, which could indicate ingestion of plants consumed by secondary prey (Rojas 1997, Duarte \& García 1999) or incidental ingestion during predation in habitat with algae. Other authors also report the presence of seaweed in snapper stomachs, at a low frequency of occurrence, ranging from $2 \%$ to $23 \%$. The role of seaweed in the nutrition of these animals is unknown (Duarte \& García 1999).

The high consumption of fish eggs by the yellow snapper indicates a high trophic specialization involving energy advantages. This high percentage of an abundant valuable food should also reduce search time and energy cost. This is consistent with the optimum foraging theory, where a predator consumes prey of high energy content to increase in size more rapidly (Duarte \& García 1999). The fish eggs have high energy content (proteins and lipids) and are easy to consume. This is the first study in snappers where fish eggs were the major food type.

The trophic overlap was high $(\lambda=0.99)$ between male and female adult yellow snapper because of the consumption of 14 prey types. The most important prey types for adults were fish eggs, mysidacea, and the sardine $H$. thrissina. In contrast, the diet overlap was low between adults and juveniles, probably because of differences in feeding habitats between juveniles and adults. Zaret \& Rand (1971) asserted that such differences in habitat use promote coexistence through partitioning of food and space.

The presence of 54 food items in the yellow snapper showed their ability to feed over a wide range of prey with a preference for certain prey types as fish eggs. The high consumption of fish eggs (62\%), and Harengula 
thrissina (23\%) indicated that yellow snapper is a selective predator, choosing prey according to food requirements. In this sense, this predator would be considered a plastic predator, which feeds on abundant prey to maximize consumption and energy use (fish eggs). However, when the food is limited, it feeds on available prey.

\section{Acknowledgments}

The first and second authors thank the Centro de Investigaciones Biológicas del Noroeste, S.C. for support received through the project 'Estructura funcional de peces en Bahía de La Paz, Baja California Sur, México’. The third and fourth authors thank the Instituto Politécnico Nacional through COFAA and EDI. Finally, thanks to Dr. Ellis Glazier for editing the English-language text, and also to two anonymous reviewers for their invaluable suggestions to this manuscript.

\section{Literature cited}

Allen GR. 1987. Synopsis of the circumtropical fish genus Lutjanus (Lutjanidae). In: Polovina JJ \& S Ralston (eds). Tropical Snappers and Groupers: Biology and Fisheries Management, pp. 33-87. Westview Press, Boulder, Colorado.

Allen GR \& DR Robertson. 1994. Fishes of the tropical eastern Pacific, 332 pp. University of Hawaii Press, Manoa.

Bastida ZJR. 1991. Poliquetos (Annelida: Polychaeta) del sureste de la bahía de La Paz, B.C.S. México. Tesis de Biología Marina. Universidad Autónoma de Baja California Sur, La Paz, México. 130 pp.

Berdegué AJ. 1956. Peces de importancia comercial en las costas noroccidental de México, 345 pp. Secretaría de Marina, División General de Pesca, México.

Brusca RC. 1980. Common intertidal invertebrates of the Gulf of California, 513 pp. The University of Arizona Press, Tucson.

Cailliet GM, MS Love \& AW Ebeling. 1986. Fishes. A field and laboratory manual on their structure identification, and natural history, 194 pp. Wadsworth Publishing Company, Belmont.

Claro R. 1981. Ecología y ciclo de vida del pargo criollo Lutjanus analis (Cuvier), en la plataforma Cubana. Informe Científico Técnico, Academia de Ciencias de Cuba 186: 1-83.

Claro R. 1983. Ecología y ciclo de vida de la rabirrubia, Ocyurus chrysurus (Bloch), en la plataforma cubana. Identificación, distribución, hábitat, reproducción y alimentación. Informe Científico Técnico, Academia de Ciencias de Cuba 15: 1-33.

Claro R \& VI Lapin. 1971. Algunos datos sobre la alimentación y dinámica de las grajas de la biajaiba Lutjanus synagris (Linnaeus) en el Golfo de Batabampo, Plataforma sur de Cuba. Instituto de Oceanología. Academia de Ciencias de Cuba, Serie Oceanológica 10(1): 10-16.

Clothier CR. 1950. A key to some southern California fishes based on vertebral characters. Fishery Bulletin 79: 1-83.
Díaz UJG. 1994. Análisis trófico del huachinango (Lutjanus peru) en las bahías de La Paz y La Ventana, B.C.S., México. Tesis de Maestría. Centro de Investigación Científica y de Educación Superior de Ensenada, Baja California, México, 57 pp.

Duarte LO \& CB García. 1999. Diet of the mutton snapper Lutjanus analis (Cuvier) from the gulf of Salamanca, Colombia, Caribbean Sea. Bulletin of Marine Science 65(2): 453-465.

Eschmeyer WN, ES Herald \& H Hamman. 1983. Pacific coast fishes, 367 pp. Houghton, Mifflin Boston.

Fischer W, F Krupp, W Schneider, C Sommer, KE Carpenter \& VH Niem. 1995. Guía FAO para la identificación de especies para los fines de la pesca. Pacífico centro-oriental. Roma. Vol. I. Plantas e invertebrados. 646 pp. FAO, Roma, Italia.

Funes M \& M Matal. 1989. Estudio sobre la reproducción y alimentación de la 'Pargueta' Lutjanus argentiventris (Lutjanidae) en Los Cobanos, Departamento de Sonsonete, El Salvador, Centro América. Tesis de Licenciatura. Universidad de El Salvador, El Salvador, 65 pp.

Guevara E, A Bosh, R Suárez \& R Lalana. 1994. Alimentación natural de tres especies de pargo (Pisces:Lutjanidae) en el Archipiélago de los Canarreos, Cuba. Revista de Investigaciones Marinas 15(1): 63-72.

Hendrickx M. 1999. Los cangrejos braquiuros (Crustacea: Brachyura: Majoidea y Parthenopodidae) del Pacífico mexicano, 274 pp. Comisión Nacional para el Conocimento y Uso de la Biodiversidad, México.

Hyslop JE. 1980. Stomach contents analysis. A review of methods and their application. Journal of Fish Biology 17: 411-429.

Iverson LK \& L Pinkas. 1971. A pictorial guide to beaks of certain eastern Pacific cephalopods. Fishery Bulletin 152: 83-105.

Krebs CJ. 1989. Ecological methodology, 473 pp. Harper and Row, New York.

Labropoulou M \& A Eleftheriou. 1997. The foraging ecology of two pairs of congeneric demersal fish species: importance of morphological characteristics in prey selection. Journal of Fish Biology 50: 324-340.

Langton RW. 1982. Diet overlap between the Atlantic cod Gadus morhua, silver hake Merluccius bilinearis and fifteen other northwest Atlantic finfish. Fishery Bulletin 80: 745-759.

Leventhal K. 1982. Foods habits of some commercial fish in the Gulf of Nicoya, Costa Rica. A.C.M. Tropical Field Research Program, Costa Rica. 31 pp.

Maeda MA. 1981. Composición, abundancia, diversidad y alimentación de la ictiofauna, en tres lagunas costeras del Golfo de California. Tesis de Biología. Universidad Autónoma de Nuevo León, Monterrey, México, 140 pp.

Maravilla DE. 2001. Época reproductiva, hábitos alimenticios, edad y crecimiento del pargo mancha L. guttatus (Steindachner, 1869) (Pisces:Lutjanidae). Los Cobanos y Puerto de la Libertad. Tesis de Licenciatura. Universidad de El Salvador, El Salvador, 73 pp.

Miller JD \& RN Lea. 1972. Guide to the Coastal Marine Fishes of California. Fishery Bulletin 157: 249. 
Miller JD \& SC Jorgensen. 1973. Meristics characters of some marine fishes of the western Atlantic Ocean. Fishery Bulletin 71(1): 301-312.

Pinkas L, MS Oliphant \& LR Iverson. 1971. Food habits of albacore, bluefin tuna, and bonito in California waters. Fishery Bulletin 152: 1-105.

Ramírez RM. 1996. Pesquería de escama. In: Casas VMM \& G Ponce D. Estudio del potencial pesquero y acuícola de Baja California Sur, pp. 287-304. SEMARNAT, FAO, INP, UABCS, CIB, CICIMAR, CETMAR, México.

Rodríguez RJ, LA Abitia, F Galván \& H Chávez. 1994. Composición, abundancia y riqueza específica de la ictiofauna de Bahía Concepción, Baja California Sur, México. Ciencias Marinas 20(3): 321-350.

Rojas MJ. 1997. Dieta del pargo colorado Lutjanus colorado (Pisces: Lutjanidae) en el Golfo de Nicoya, Costa Rica. Revista de Biología Tropical 45(3): 1173-1183.

Rojas MJ. 1996-1997. Hábitos alimentarios del pargo mancha Lutjanus guttatus (Pisces: Lutjanidae) en el Golfo de Nicoya, Costa Rica. Revista de Biología Tropical 44(3)/45(1): 471476.

Rojas HAA \& XC Chiappa. 2002. Hábitos alimenticios del flamenco Lutjanus guttatus (Pisces: Lutjanidae) en la costa de Guerrero, México. Ciencias Marinas 28(2): 133-147.

Rooker J. 1995. Feeding ecology of the schoolmaster snapper, Lutjanus apodus (Walbaum), from southwestern Puerto Rico. Bulletin of Marine Science 56(3): 881-894.
Sámano ZJC, ME Vega \& MS Hernández. 1998. Ecología alimenticia e interacción trófica del pargo mulato Lutjanus griseus (Linnaeus, 1758) y de la rubia Lutjanus synagris (L. 1758) de la costa Noroccidental de la Península de Yucatán, México. Proceedings of the $50^{\text {th }}$ Gulf and Caribbean Fisheries Institute 50: 805-826.

Sierra LM, R Claro \& OA Popota. 1994. Alimentación y relaciones tróficas. In: Claro R (ed), Ecología de los peces marinos de Cuba, pp. 263-320. Instituto de Oceanología. Academia de Ciencias de Cuba y Centro de Investigaciones de Quintana Roo, México.

Smith PE \& MT Zaret. 1982. Bias in estimating niche overlap. Ecology 63(5): 1248-1253.

Stillwell CE \& NE Kohler. 1982. Food, feeding habits, and estimates of daily ration of the shortfin mako (Isurus oxyrhincus) in the northern Atlantic. Canadian Journal of Fisheries and Aquatic Science 39: 407-414.

Thomson D, L Findley \& A Kerstich. 2000. Reef fishes of the Sea of Cortez. The Rocky-Shore Fishes of the Gulf of California, 374 pp. University of Texas Press, Texas.

Zaret TM \& AS Rand. 1971. Competition in stream fishes: support for the competitive exclusion principle. Ecology 52: 336-342.

Recibido el 7 de marzo de 2008 y aceptado el 13 de mayo de 2008 